\title{
DINAMIKAI FELADATOK MEGOLDÁSA SOROZATOK KONVOLÚCIÓJÁNAK SEGÍTSÉGÉVEL
}

\author{
BIRI SALAH*
}

A műszaki folyamatok modellezésére gyakran első-, illetve másodrendű differenciálegyenleteket, illetve -rendszereket használnak. E differenciálegyenletek analitikus megoldására gyakran Laplace-féle integrál-transzformációt használnak, amely csak nehezen kezelhető, és gépi számításokra körülményesen alkalmazható.

Jelen cikk egy új módszert mutat be a dinamikai rendszerek rezgéseinek kiszámítására. A feladatot sorozatok konvolúciójának segítségével oldja meg, az alkalmazására példákat mutat be, és összehasonlítja más módszerekkel kapott eredményekkel.

Kulcsszavak: konvolúció, sorozat, dinamika, rezgés

\section{SOROZATOK KONVOLÚCIÓJA}

Tegyük fel, hogy van egy

$$
a=\left[a_{0}, a_{1}, \ldots, a_{n}\right]
$$

és egy

$$
b=\left[b_{0}, b_{1}, \ldots, b_{m}\right]
$$

véges, de akármeddig folytatható numerikus sorozatunk.

* okleveles építőmérnök, PhD. E-mail: birisalah@freemail.hu 
A két sorozat konvolúciója definíció szerint [4], [8]:

$$
c_{t}=\sum_{k=0}^{t} a_{k} b_{t-k}=\sum_{k=0}^{t} b_{k} a_{t-k}, \quad t=0 \cdot n+m .
$$

A két sorozat karakterisztikus függvénye:

$$
\begin{aligned}
& A(x)=a_{0}+a_{1} x+a_{2} x^{2}+\ldots+a_{n} x^{n}, \\
& B(x)=b_{0}+b_{1} x+b_{2} x^{2}+\ldots+b_{m} x^{m},
\end{aligned}
$$

amelyek szorzat-polinomja:

$$
A(x) \cdot B(x)=\sum_{k=0}^{t} a_{k} b_{t-k} x^{t} .
$$

Mint látható az $x^{t}$ tag együtthatója megegyezik a (3)-beli $c_{t}$-vel, amelyet a két sorozat konvolúciójával nyertünk. Ha folytonos függvényekkel keressük a kapcsolatot, nem érdektelen a (3)-at az $f(t)$ és $g(t)$ folytonos függvények (6) konvolúciójával összekapcsolni [6],[12].

$$
k(t)=f(t) * g(t)=\int_{0}^{t} f(\tau) \cdot g(t-\tau) \cdot d x=\int_{0}^{t} f(t-\tau) \cdot g(\tau) \cdot d \tau
$$

Innen származik a gondolat, hogy folytonos függvények helyett inkább numerikus sorozatokkal [11] dolgozzunk.

Tegyük fel, hogy (1) sorozat elemei nem skalárok, hanem vektorok:

$$
a=\left[\mathbf{a}_{0}, \mathbf{a}_{1}, \ldots, \mathbf{a}_{n}\right],
$$

ahol

$$
\mathbf{a}_{t}=\left[\begin{array}{c}
a_{t, 1} \\
a_{t, 2} \\
\vdots \\
a_{t, p}
\end{array}\right],
$$

és (2) sorozat elemei pedig mátrixok:

$$
b=\left[\mathbf{B}_{0}, \mathbf{B}_{1}, \ldots, \mathbf{B}_{m}\right],
$$


ahol

$$
\mathbf{B}_{t}=\left[\begin{array}{cccc}
b_{t, 11} & b_{t, 12} & \ldots & b_{t, 1 p} \\
b_{t, 21} & b_{t, 22} & \ldots & b_{t, 2 p} \\
\vdots & \vdots & \ldots & \vdots \\
b_{t, q 1} & b_{t, q 2} & \ldots & b_{t, q p}
\end{array}\right]
$$

akkor (7) és (8) sorozatok konvolúciója [1], [3], [5]:

$$
\mathbf{c}_{t}=\sum_{k=0}^{t} \mathbf{B}_{k} \mathbf{a}_{t-k}, \quad t=0 \cdot n+m
$$

ahol

$$
\mathbf{c}_{t}=\left[\begin{array}{c}
c_{t, 1} \\
c_{t, 2} \\
\vdots \\
c_{t, q}
\end{array}\right]
$$

Az a sorozat karakterisztikus függvénye egy vektoregyütthatós polinom:

$$
A(x)=\mathbf{a}_{0}+\mathbf{a}_{1} x+\mathbf{a}_{2} x^{2}+\cdots+\mathbf{a}_{n} x^{n},
$$

a $b$ sorozat karakterisztikus függvénye pedig egy mátrixegyütthatós polinom:

$$
B(x)=\mathbf{B}_{0}+\mathbf{B}_{1} x+\mathbf{B}_{2} x^{2}+\cdots+\mathbf{B}_{m} x^{m},
$$

amelyek szorzat-polinomja:

$$
C(x)=\mathbf{c}_{0}+\mathbf{c}_{1} x+\mathbf{c}_{2} x^{2}+\cdots+\mathbf{c}_{n+m} x^{n+m},
$$

ahol $\mathbf{c}_{t}$ együttható a $b$ mátrixsorozat és az $a$ vektorsorozat konvolúciójából (1. ábra) származik.

A sorozatok konvolúcióját több múszaki probléma megoldásában lehet alkalmazni. Ha az $a$ sorozatot a tényleges ok sorozatának tekintjük, és a $b$ sorozatot az egységhatás válaszsorozatának tekintjük, akkor az okozat a (3) szerint kiszámítható. Jelen cikkben ezt fogjuk alkalmazni a dinamikai rendszerek rezgéseinek kiszámításához. 


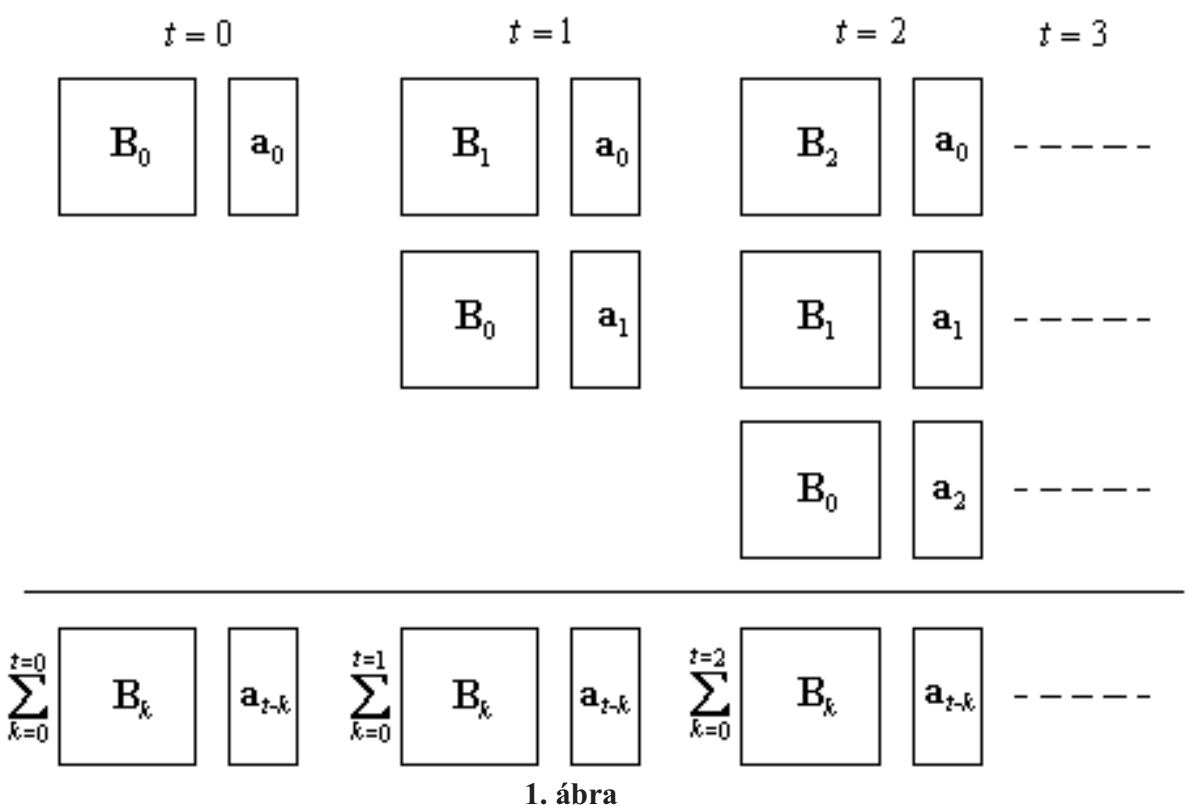

\section{EGY SZABADSÁGFOKÚ RENDSZER, IDŐTŐL TETSZŐLEGESEN FÜGGŐ GERJESZTETT ERŐ ESETÉN}

Az egy szabadságfokú rendszer gerjesztett rezgésének egy egyszerü modellje a 2. ábrán látható. Az $f(t)$ erővel gerjesztett csillapítatlan rezgés differenciálegyenlete [9]:

$$
m \ddot{x}+k x=f(t),
$$

ahol $k$ a rúgó merevsége, $m$ az anyagi pont tömege, $x$ az anyagi pont elmozdulása és $\ddot{x}$ az anyagi pont gyorsulása.

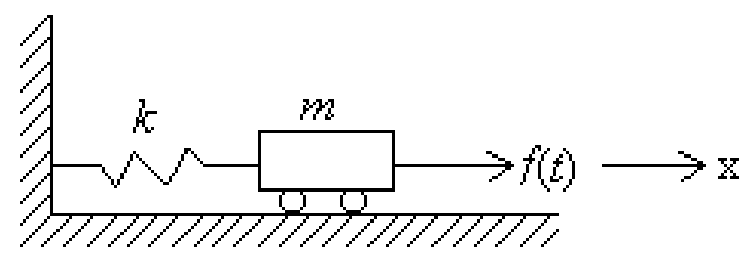

2. ábra 
A (13) differenciálegyenlet általános megoldása:

$$
x(t)=K_{1} \cos (\omega t)+K_{2} \sin (\omega t)+\frac{1}{m \omega} \int_{0}^{t} f(\tau) \cdot \sin \omega(t-\tau) \cdot d \tau,
$$

ahol

$$
\omega=\sqrt{\frac{k}{m}}
$$

a saját-körfrekvencia.

Ha feltételezzük, hogy $t=0$ időpontban $x(0)=0$ és $\dot{x}(0)=0$, akkor $K_{1}=K_{2}=0$, így a (13) differenciálegyenlet kezdeti feltételeket kielégítő megoldása:

$$
x(t)=\frac{1}{m \omega} \int_{0}^{t} f(\tau) \cdot \sin \omega(t-\tau) \cdot d \tau .
$$

A (15)-ből látható, hogy a rezgés az $f(t)$ és $\sin (\omega t)$ folytonos függvények konvolúciója:

$$
x(t)=\frac{1}{m \omega} f(t) * \sin (\omega t) .
$$

Most feltételezzük, hogy az $f(t)$ egy $\Delta t$ időig tartó egység erő, vagyis (3. ábra):

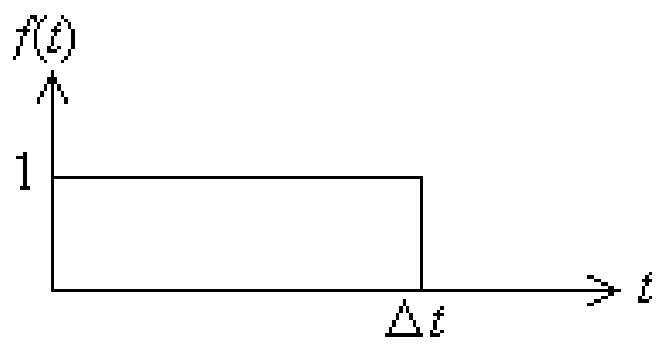

3. ábra

$$
\begin{array}{ll}
f(t)=1, & \text { ha } t \leq \Delta t \\
f(t)=0, & \text { ha } t>\Delta t,
\end{array}
$$


akkor a rezgés függvénye az alábbi lesz:

$$
\begin{array}{ll}
x(t)=\frac{1}{k}(1-\cos (\omega t)), & \text { ha } t \leq \Delta t \\
x(t)=\frac{1}{k}(\cos \omega(t-\Delta t)-\cos (\omega t)), & \text { ha } t>\Delta t .
\end{array}
$$

A (18) függvényt nevezzük az egységhatás válaszfüggvénynek. Ha a fenti függvényből készítünk egy sorozatot úgy, hogy $\Delta t$ időközönként leolvassuk a (18) függvény ordinátáit és azokat egy sorozatban foglaljuk össze, akkor megkapjuk $a z$ egységhatás válaszsorozatát. Ugyanígy a tényleges erőfüggvényből készítünk egy másik sorozatot, akkor megkapjuk a tényleges ok sorozatát. A tényleges rezgések a két sorozat konvolúciójából (3) szerint számíthatók ki.

\section{Számpélda}

Számítsuk ki a 4. ábrán látható konzol tartó szabad végének $y$ irányú rezgéseit.

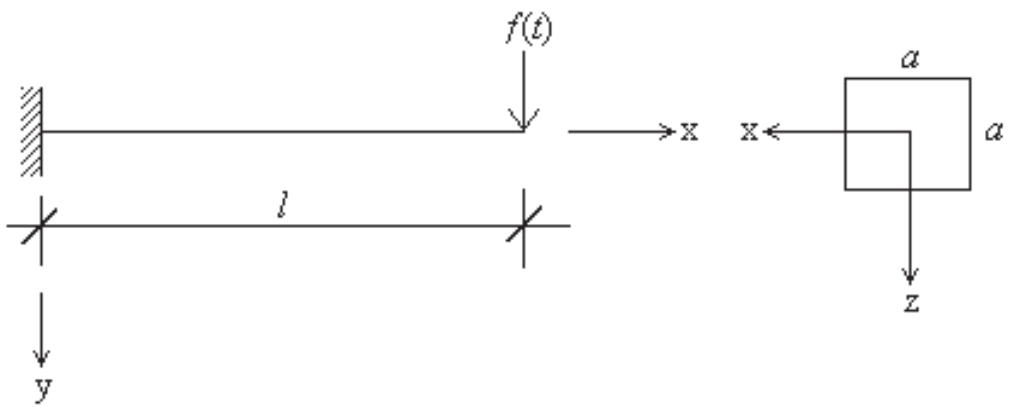

\section{4. ábra}

Adatok: $l=1 \mathrm{~m}, a=10 \mathrm{~cm}, E=2 \cdot 10^{8} \mathrm{kN} / \mathrm{m}^{2}, \rho=7,85 \mathrm{to} / \mathrm{m}^{3}, k=3 \mathrm{EJ} / l^{3}=5000$ $\mathrm{kN} / \mathrm{m}$.

Redukáljuk a szerkezet tömegének a felét a konzol szabad végére:

$$
\begin{gathered}
\mathrm{m}=\rho A l / 2=0,03925 \text { to és } \sqrt{\frac{k}{m}}=356,9151 / \mathrm{s}, \\
f(t)=Q \cdot \sin \left(\omega_{g} t\right),
\end{gathered}
$$

ahol $Q=1 \mathrm{kN}$ és $\omega_{g}=2501 / \mathrm{s}$. 
Olvassuk a (18) függvény ordinátáit $\Delta t=0,001 \mathrm{~s}$ időközönként $t_{\max }=0,06 \mathrm{~s}$ időig, és foglaljuk össze egy sorozatba. Ez lesz az egységhatás válaszsorozata. A (19) teherfüggvényből is készítünk egy másik sorozatot, amely tényleges ok sorozata lesz úgy, hogy a két szomszédos ordinátának az átlagát vesszük:

$$
a_{i}=\frac{f(t)+f(t+\Delta t)}{2}, \quad t=i \Delta t
$$

A konzolvég y irányú rezgéseit végül a fenti két sorozat konvolúciójával tudjuk kiszámítani (3) szerint.

A feladat analitikus megoldása [9]:

$$
x(t)=\frac{Q}{k} \cdot \frac{1}{1-\left(\frac{\omega_{g}}{\omega}\right)^{2}} \cdot\left(\sin \left(\omega_{g} t\right)-\frac{\omega_{g}}{\omega} \sin (\omega t)\right) .
$$

Az 5. ábra mutatja a két megoldást, ahol a sorozatok konvolúciójának segítségével kiszámított rezgéseket négyzetekkel, az analitikusan kiszámított rezgéseket pedig keresztekkel jelöltük meg.

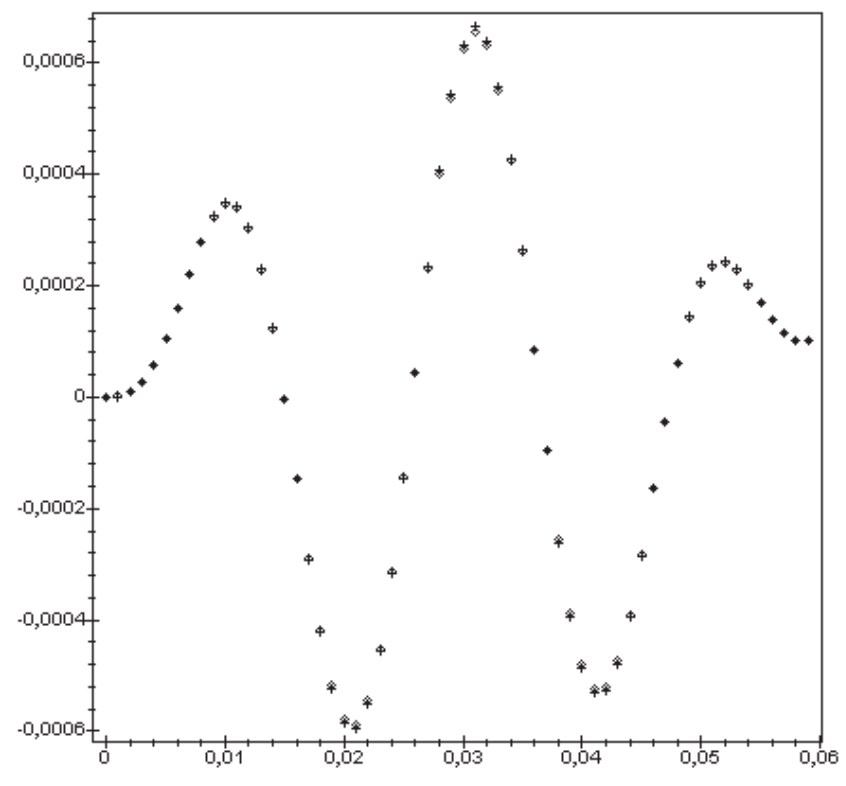

5. ábra 
Érdemes megjegyezni, hogy amikor rezonancia jelenség van, vagyis amikor $\omega=\omega_{g}$, a (20)-as helyett egy más megoldást kell alkalmazni (21), a sorozatok konvolúciójával azonban továbbra is ugyanazon eljárással lehet számítani a rezgéseket. Az eredmények megegyeznek az irodalomban találhatókkal.

$$
\lim _{\omega_{g} \rightarrow \omega} x(t)=\frac{Q}{2 k} \cdot \sin (\omega t)-\frac{Q \omega}{2 k} t \cdot \cos (\omega t) .
$$

\section{TÖBB SZABADSÁGFOKÚ RENDSZER CSILLAPÍTATLAN REZGÉSEI}

A több szabadságfokú rendszert az alábbi differenciálegyenlet-rendszerrel lehet modellezni [9], [13]:

$$
\mathbf{M} \ddot{\mathbf{x}}+\mathbf{K x}=\mathbf{f}(t)
$$

ahol $\mathbf{M}$ a tömegmátrix, $\mathbf{K}$ a merevségi mátrix, $\mathbf{x}$ az elmozdulás vektorfüggvény, $\ddot{\mathbf{x}}$ az $\mathbf{x}$ időszerinti második deriváltja és $\mathbf{f}(t)$ pedig a teher vektorfüggvény.

A szerkezet egységhatás válasz-mátrixfüggvényét úgy határozhatjuk meg, hogy a (22) differenciálegyenlet-rendszer jobb oldalán egységnyi időig tartó egység terheket múködtetünk, tehát:

$$
\mathbf{M X}+\mathbf{K X}=\mathbf{E} .
$$

Szorozzuk a (23)-t balról $\mathbf{M}^{-1}$-nel:

$$
\ddot{\mathbf{X}}+\mathbf{M}^{-1} \mathbf{K X}=\mathbf{M}^{-1} .
$$

Bontsuk fel az $\mathbf{M}^{-1} \mathbf{K}$ mátrixot az alábbi formára:

$$
\mathbf{M}^{-1} \mathbf{K}=\mathbf{U} \Lambda \mathbf{U}^{-1},
$$

ahol $\mathbf{U}$ az $\mathbf{M}^{-1} \mathbf{K}$ mátrix sajátvektorainak mátrixa és $\Lambda$ pedig sajátértékeinek mátrixa.

Így a (24) a következőképpen alakul:

$$
\ddot{\mathbf{X}}+\mathbf{U} \Lambda \mathbf{U}^{-1} \mathbf{X}=\mathbf{M}^{-1} .
$$

Szorozzuk meg a (26)-öt balról $\mathbf{U}^{-1}$-nel:

$$
\mathbf{U}^{-1} \ddot{\mathbf{X}}+\Lambda \mathbf{U}^{-1} \mathbf{X}=\mathbf{U}^{-1} \mathbf{M}^{-1}
$$


Legyen $\mathbf{Y}=\mathbf{U}^{-1} \mathbf{X}$ és $\mathbf{P}=\mathbf{U}^{-1} \mathbf{M}^{-1}$, akkor a (27) következő lesz:

$$
\ddot{\mathbf{Y}}+\Lambda \mathbf{Y}=\mathbf{P} \text {. }
$$

Tehát (23) szétesett független differenciálegyenletekre, amelynek megoldása az $\mathbf{X}(0)=\mathbf{0}$ és $\dot{\mathbf{X}}(0)=\mathbf{0}$ kezdeti feltételek mellett (18) alapján:

$$
\begin{array}{ll}
\mathbf{Y}_{i j}(t)=\frac{\mathbf{P}_{i j}}{\Lambda_{i i}}\left(1-\cos \left(\sqrt{\Lambda}_{i i} t\right)\right), & \text { ha } t \leq \Delta t \\
\mathbf{Y}_{i j}(t)=\frac{\mathbf{P}_{i j}}{\Lambda_{i i}}\left(\cos \sqrt{\Lambda_{i i}}(t-\Delta t)-\cos \left(\sqrt{\Lambda}_{i t} t\right)\right), & \text { ha } t>\Delta t .
\end{array}
$$

Ezek után az egységhatás válasz-mátrixfüggvénye meghatározható:

$$
\mathbf{X}(t)=\mathbf{U Y}(t) .
$$

Az egységhatás válasz-mátrixsorozatát úgy kapjuk meg, hogy $\Delta t$ időközönként leolvassuk a $\mathbf{X}(t)$ mátrixfüggvény ordinátáit $t_{\max }$ időpontig, majd ezeket egy mátrixsorozatba foglaljuk össze.

A teher vektorfüggvényből ugyanígy készíthetünk egy vektorsorozatot, és akkor megkapjuk a tényleges ok vektorsorozatát.

A szerkezet csomópontjainak a rezgéseit végül a fenti két sorozat konvolúciójából (9) szerint nyerhetjük meg.

\section{Számpélda}

Számítsuk ki a 6. ábrán látható síkbeli keret 1-es és 2-es csomópontjainak a rezgéseit.

Adatok: $a=10 \mathrm{~cm}, E=7,1 \cdot 10^{6} \mathrm{kN} / \mathrm{m}^{2}, \rho=2,5 \mathrm{to} / \mathrm{m}^{3}, Q=10 \mathrm{kN}, M=20 \mathrm{kNm}$, $m_{12}=\rho \cdot A \cdot l_{12}, \quad m_{13}=\rho \cdot A \cdot l_{13}, \quad m_{24}=\rho \cdot A \cdot l_{24}, \quad m_{1}=\frac{m_{12}+m_{13}}{2}=0,125$, $m_{2}=\frac{m_{12}+m_{24}}{2}=0,125$ to.

A szerkezet tömegmátrixa:

$$
\mathbf{M}=\left[\begin{array}{llllll}
0,125 & & & & & \\
& 0,125 & & & & \\
& & 0,125 & & & \\
& & & 0,125 & & \\
& & & & 0,125 & \\
& & & & & 0,125
\end{array}\right] .
$$




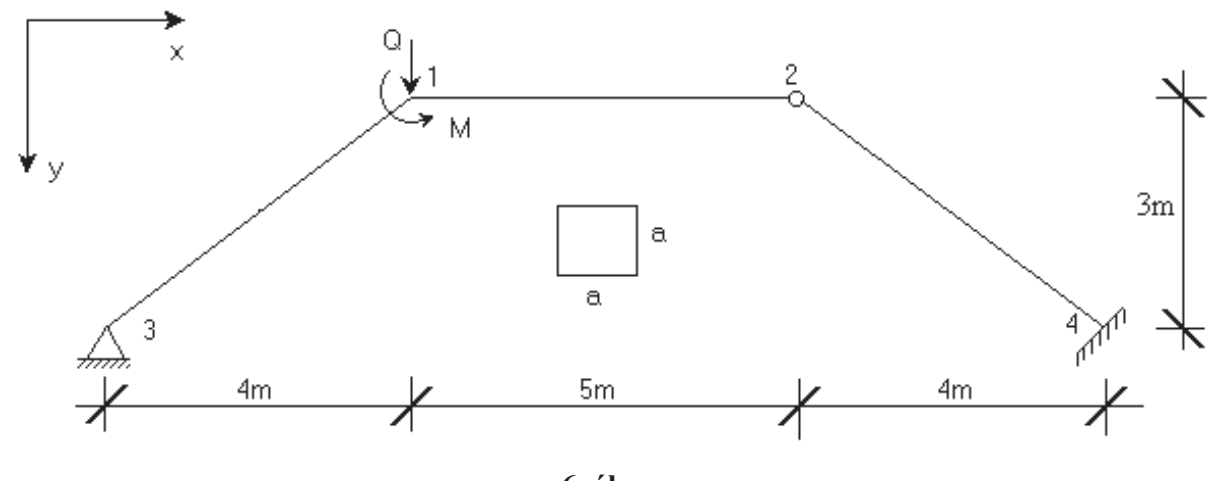

6. ábra

A szerkezet merevségi mátrixa [7]:

$$
\mathbf{K}=\left[\begin{array}{cccccc}
23288,511 & -6815,318 & -4,260 & -14200,000 & 0 & 0 \\
& 5114,329 & 1,420 & 0 & -1,420 & 0 \\
& & 71,000 & 0 & -7,100 & 0 \\
& & & 23290,045 & 6813,274 & -8,520 \\
& \text { szimm. } & & & 5117,055 & 11,360 \\
& & & & & 47,333
\end{array}\right] .
$$

Az $\mathbf{M}^{-1} \mathbf{K}$ mátrix sajátértékeinek mátrixa:

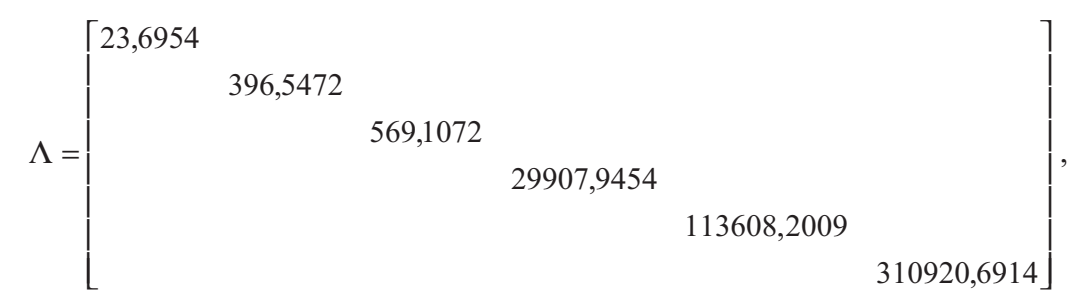

és sajátvektorainak mátrixa:

$$
\mathbf{U}=\left[\begin{array}{cccccc}
0,413442 & 0,093491 & -0,021150 & 0,139718 & 0,565645 & 0,693111 \\
0,551128 & 0,125779 & -0,028293 & 0,692823 & -0,424318 & -0,139955 \\
-0,043140 & -0,030294 & -0,998609 & -0,001236 & -0,000426 & -0,000056 \\
0,413472 & 0,092644 & -0,020702 & -0,140163 & 0,565645 & -0,693131 \\
-0,551246 & -0,122381 & 0,0264947 & 0,693414 & 0,424319 & -0,139928 \\
0,220523 & -0,975172 & 0,020053 & 0,002458 & 0,0000000 & 0,000111
\end{array}\right],
$$


és

$$
\mathbf{P}=\left[\begin{array}{cccccc}
3,307538 & 4,409027 & -0,345123 & 3,307774 & -4,409970 & 1,764188 \\
0,747930 & 1,006234 & -0,242349 & 0,741150 & -0,979050 & -7,801379 \\
-0,169201 & -0,226348 & -7,988870 & -0,165616 & 0,211957 & 0,160423 \\
1,117745 & 5,542582 & -0,009892 & -1,121301 & 5,547308 & 0,019661 \\
4,525157 & -3,394546 & -0,003411 & 4,525157 & 3,394548 & 0,000000 \\
5,544886 & -1,119636 & -0,000445 & -5,545046 & -1,119423 & 0,000889
\end{array}\right] .
$$

Legyen $\Delta t=0,03 \mathrm{~s}$ és $t_{\max }=1,0 \mathrm{~s}$, akkor $\mathbf{Y}$ mátrix (29) szerint kiszámítható és ezután az egységhatás válasz-mátrixfüggvénye is meghatározható (30) szerint.

A $\mathbf{X}(t)$ mátrixfüggvény ordinátáit leolvassuk $\Delta t$ időközönként majd összefoglaljuk egy mátrixsorozatba, akkor megkapjuk az egységhatás válasz-mátrixsorozatát.

A tényleges ok vektorfüggvénye legyen:

$$
\begin{aligned}
\mathbf{f}(t) & =\left[\begin{array}{c}
0 \\
Q \\
-M \\
0 \\
0 \\
0
\end{array}\right] \\
\mathbf{f}(t) & =\left[\begin{array}{l}
0 \\
0 \\
0 \\
0 \\
0 \\
0
\end{array}\right]
\end{aligned}
$$

Olvassuk le az $\mathbf{f}(t)$ vektorfüggvény ordinátáit $\Delta t$ időközönként és foglaljuk össze egy vektorsorozatba, akkor megkapjuk a tényleges ok vektorsorozatát.

Végül a csomópontok rezgései a (9) szerint kiszámíthatók (7. ábra): 


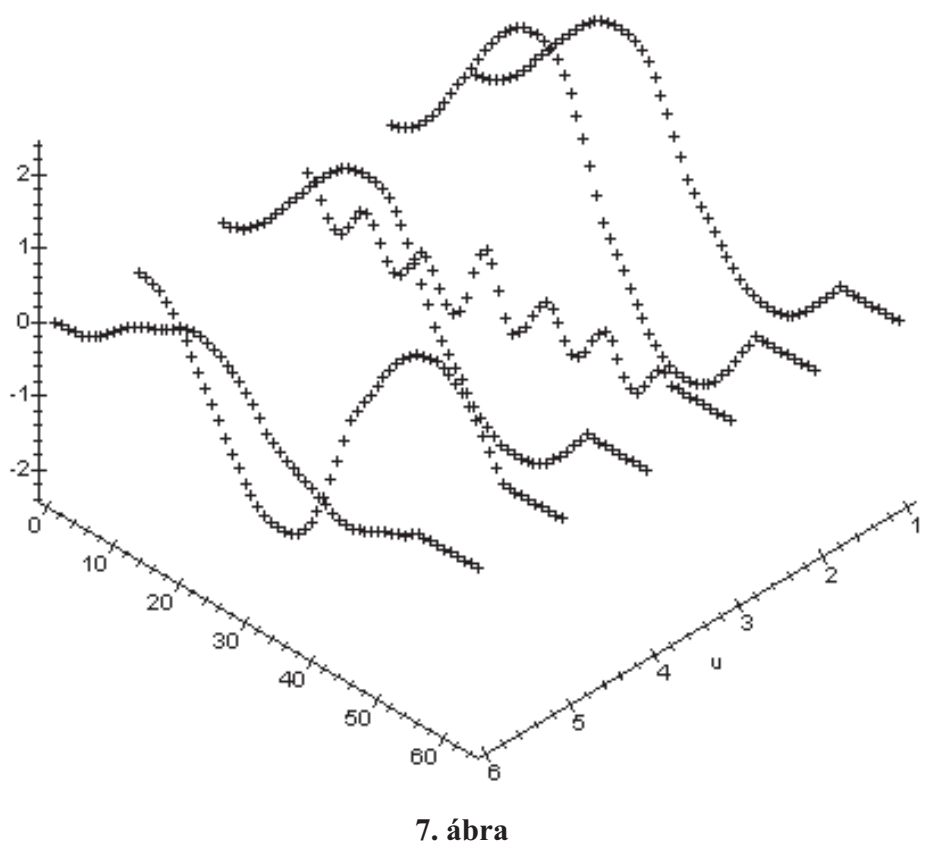

\section{4. ÖSSZEHASONLÍTÓ PÉLDA}

Számítsuk ki a 8. ábrán látható négyzet keresztmetszetü rudakból álló síkbeli keret 3-as csomópontjának vízszintes rezgéseit Newmark-eljárással és sorozatok kovolúciójával.

Adatok: $a=20 \mathrm{~cm}, l=3,0 \mathrm{~m}, E=7,1 \cdot 10^{6} \mathrm{kN} / \mathrm{m}^{2}, \rho=2,5 \mathrm{to} / \mathrm{m}^{3}, N=10 \mathrm{kN}$.

A Newmark-eljárással először a kezdeti feltételeket adjuk meg: $\mathbf{x}_{0}=\mathbf{0}$ és $\dot{\mathbf{x}}_{0}=\mathbf{0}$, míg $\ddot{\mathbf{x}}_{0}$ vektor a (31) egyenletrendszerből számítható.

$$
\mathbf{M} \ddot{\mathbf{x}}_{0}+\mathbf{K} \mathbf{x}_{0}=\mathbf{f}_{0} .
$$

Majd a rezgéseket az $i$-edik lépésben az alábbi egyenletrendszer szerint kiszámítjuk [2], [11]:

$$
\hat{\mathbf{K}} \mathbf{x}_{i}=\mathbf{p}_{i},
$$

ahol

$$
\begin{gathered}
\hat{\mathbf{K}}=a_{1} \mathbf{M}+\mathbf{K}, \\
\mathbf{p}_{i}=\mathbf{f}_{i}+a_{1} \mathbf{M} \mathbf{X}_{i-1}+a_{6} \mathbf{M} \dot{\mathbf{x}}_{i-1}+a_{7} \mathbf{M} \ddot{\mathbf{x}}_{i-1},
\end{gathered}
$$




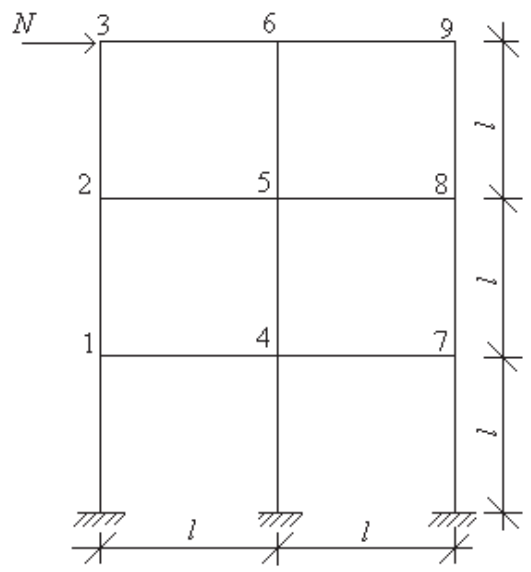

8. ábra

$$
\begin{aligned}
& \dot{\mathbf{x}}_{i}=a_{3}\left[\mathbf{x}_{i}-\mathbf{x}_{i-1}\right]+a_{4} \dot{\mathbf{x}}_{i-1}+a_{5} \ddot{\mathbf{x}}_{i-1}, \\
& \ddot{\mathbf{x}}_{i}=a_{1}\left[\mathbf{x}_{i}-\mathbf{x}_{i-1}-\Delta t \dot{\mathbf{x}}_{i-1}\right]+a_{2} \ddot{\mathbf{x}}_{i-1}
\end{aligned}
$$

és

$$
\begin{gathered}
a_{1}=\frac{1}{\beta \Delta t^{2}}, \quad a_{2}=1-\frac{1}{2 \beta}, \quad a_{3}=\frac{\alpha}{\beta \Delta t}, \quad a_{4}=1-\frac{\alpha}{\beta} \\
a_{5}=\left(1-\frac{\alpha}{2 \beta}\right) \Delta t, \quad a_{6}=\frac{1}{\beta \Delta t}, \quad a_{7}=\frac{1}{2 \beta}-1 .
\end{gathered}
$$

Az $\alpha$ és $\beta$ paramétereknek az eljárás stabilitásában és pontosságában van szerepe. Az eljárás feltétlenül stabil, ha az

$$
\alpha \geq \frac{1}{2}, \quad \beta \geq \frac{1}{4}\left(\frac{1}{2}+\alpha\right)^{2} .
$$

Az előző fejezetben leírtak szerint megoldjuk a feladatot a sorozatok konvolúciójának segítségével is.

Az eredményeket $\alpha=0,5, \beta=0,25$ és $\Delta t=0,0375 \mathrm{~s}$ esetén a 9. ábrán foglaltuk össze, ahol az analitikusan kapott eredményeket körrel, a Newmark-eljárással kapott eredményeket négyzettel és a sorozatok konvolúciójával kapott eredményeket pedig kereszttel jelöltük meg. A vízszintes vonal a statikus eredmény. 


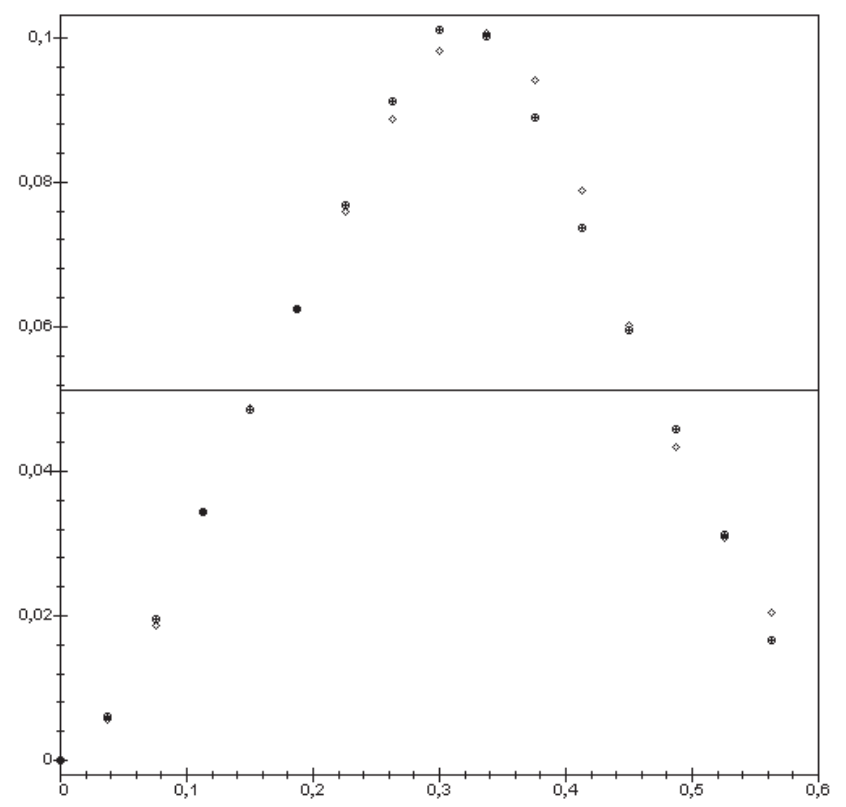

9. ábra

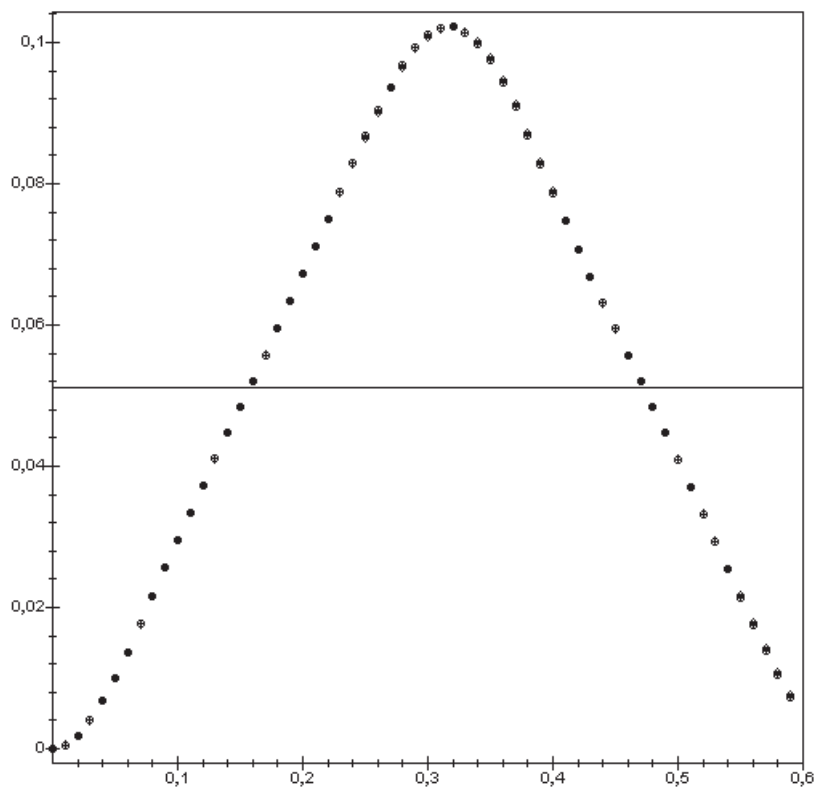

10. ábra 
Mint látható a keresztek belefekszenek a körökbe, ami a módszer pontosságára utal, a négyzetek majdnem mindegyike viszont a körön kívül esik, ami a Newmark-eljárás kevésbé pontos voltára utal. A Newmark-eljárás pontosságát $\Delta t$ csökkentésével lehet növelni, pl. $\Delta t=0,01 \mathrm{~s}$ esetén már közelítőleg jó eredményt kapunk (10. ábra).

\section{KONKLÚZIÓ}

Az előzőekből megállapítható, hogy a feladatokat sorozatok konvolúciójának segítségével sokkal könnyebb megoldani, mint analitikusan, pl. Laplace-féle integrál-transzformáció segítségével, hiszen az első esetben szinte érdektelen, hogy milyen a differenciálegyenlet-rendszer jobb oldala, a második esetben viszont annyiszor kell újra megoldani, ahányszor más és más a differenciálegyenlet-rendszer jobb oldala. Ha a jobb oldalon egy bonyolultabb vektorfüggvény szerepel, akkor a differenciálegyenlet-rendszer analitikus megoldásának megkeresése további nehézséget jelent.

\section{IRODALOM}

[1] Alhusain, O. - Biri, S. - Holnapy, D.: Generalized Cascade Model and its Application in Bar Structure. Periodica Polytechnica 2004. évf. 1. sz. 3-14. old.

[2] Bathe, K. J. - Wilson, E. L.: Numerical Methods in Finite Element Analysis. Prentice-Hall, New Jersey, 1976.

[3] Biri S. - Holnapy D.: Egy általánosított kaszkád-modell és alkalmazása. Hidrológiai Közlöny 2003. évf. 4. sz. 239-242. old.

[4] Biri S. - Holnapy D.: Reológiai modellek és a konvolutórikus simítás kapcsolata. Geomatikai Közlemények 7 (2004), 171-179.

[5] Biri S.: Rúd- és egyéb mérnöki szerkezetek állapotváltozási egyenletének felhasználása konvolutórikus feladatok megoldásában. PhD értekezés, Budapest 2005.

[6] Detrekői Á.: Kiegyenlitő számitások. Tankönyvkiadó, Budapest, 1991.

[7] Gáspár Zs.: Tartók statikája III. Rúdszerkezetek. Múegyetemi Kiadó, Budapest, 2000.

[8] Graham, R. L. - Knuth, D. E. - Patashnik, O.: Konkrét matematika. Múszaki Könyvkiadó, Budapest, 1998.

[9] Györgyi J.: Dinamika. Múegyetemi Kiadó, Budapest, 2003.

[10] Györgyi J.: Szerkezetek dinamikája. Kézirat, 2004.

[11] Holnapy D.: Sorozatok konvolúciójának alkalmazásai. Épités-Épitészettudomány 31/1-2 (2003), pp. 61-68.

[12] Kármán T. - Biot, M. A.: Matematikai módszerek müszaki feladatok megoldására. 2. kiadás. Müszaki Könyvkiadó, Budapest, 1967.

[13] Pestel, E. C. - Leckie, F. A.: Matrix Methods in Elastomechanics. McGraw-Hill Book Company, Inc., 1963. 


\section{SOLVING DYNAMIC PROBLEMS BY HELP OF CONVOLUTION OF SERIES}

\section{Summary}

Differential equations or equation systems of first or second order are often applied for modelling technical processes. For the solution of these problems the Laplace transformation is suitable, which is handled with considerable difficulty.

This study shows an new method, which solves the problems by help of convolution of series and it's application on dynamic systems.

Keywords: convolution, series, dynamic, vibration 